\title{
The System Approach in the Perspective of Law Number 20 of 2003 concerning the National Education System
}

\author{
Siraj 1,a, Sayni Nasrah 2,b, Trisfayani 2,c \\ ${ }_{1}^{1}$ Department of Physical Education, Universitas Almuslim, Matangglumpang Dua, Bireuen, Indonesia \\ 2 Department of Indonesian Language Education, Universitas Malikussaleh, Aceh Utara, Indonesia \\ ${ }^{*}$ Corresponding Author : say_nasrah@yahoo.co.id
}

How to Cite: Siraj, S. Nasrah, S., Trisfayani, T. (2019). The System Approach in the Perspective of Law Number 20 of 2003 concerning the National Education System. International Journal for Educational and Vocational Studies, 1(1), 47-52. DOI: https://doi.org/10.29103/ijevs.v1i1.1465

\section{ARTICLE HISTORY}

Received: 8 March 2019

Revised: 24 April 2019

Accepted: 7 May 2019

\section{KEYWORDS}

System Approach

Decentralization

Education

\begin{abstract}
In the context of implementing decentralization in the education sector, there are many problems that arise, because the implementation of decentralization of education is different from the decentralization of other areas of government which is basically concentrated at the district and city level. Decentralization of education has not only stalled at the district and city level but even more so that it reaches the school level. The existence of autonomy in the management of education is a potential for schools to improve the performance of personnel, offer direct participation from relevant parties, and increase public understanding of the implementation of education in schools. Decentralization of education has encouraged the improvement of services in the field of education to the community, which leads to efforts to improve the quality of education management at the lowest level, namely schools through the implementation of School-Based Management. The implementation of School-Based Management in general is to empower or empower schools through giving authority to schools, giving schools greater flexibility to manage school resources, and encouraging the participation of school members and communities to improve the quality of education.
\end{abstract}

This is an open access article under the CC-BY-SA license.

\section{INTRODUCTION}

Regional autonomy as a form of decentralization of government is essentially aimed at fulfilling the interests of the nation as a whole, namely efforts to get closer to the objectives of governance to realize the ideals of a better society, a more just and prosperous society. In the context of regional autonomy, it is emphasized that the nationalistic national education system has so far not encouraged the democratization and decentralization of education. Because a centralized education system is recognized as being less able to accommodate regional diversity, diversity of schools, and diversity of students, it tends to turn off community participation in the development of education.

With the presence of Law Number 23 of 2014 concerning Regional Government, where a number of authorities have been handed over by the central government to regional governments, enabling regions to create, innovate and improvise in their regional development efforts including in the education sector. Law Number 23 Year 2014 Article 12 (1) states that Obligatory Government Affairs relating to Basic Services as referred to in Article 11 paragraph (2) include: a) education; b) health; c) public works and spatial planning; d) public housing and residential areas; e) peace, public order and community protection; and f) social. The implementation of regional autonomy has implications for changes in the implementation of education, one of which is the reduced role of the central government in the management of education.

In the context of implementing decentralization in the education sector, there have been many problems arising, because the implementation of decentralization of education is different from the decentralization of other areas of government which is basically concentrated at the district and city levels. Decentralization of education has not only stalled at the district and city level but even more so that it reaches the school level. The existence of autonomy in the management of education is a potential for schools to improve the performance of personnel, offer direct participation from relevant parties, and increase public understanding of the implementation of education in schools.

The emergence of a paradigm of school-based management that relies on the creation of a climate that democratizes and gives wider trust to schools to organize education efficiently and with quality. The pattern of the education sector above by Law No. 20 of 2003 concerning the National 
Education System with Article 51 stipulates that Management of early childhood education, basic education, and secondary education is carried out based on minimum service standards with the principle of school/madrasah-based management.

In the management of education in schools is a planned and organized process. This activity aims to produce positive changes in the world of education toward students' maturity. In the teaching and learning process, management of a planned teaching and learning process is needed. School management focuses on all efforts located in the teaching and learning process. Success in learning can be supported by principals, teachers, school committees and adequate facilities and infrastructure.

In order for schools to be empowered optimally, schools need to be given trust and authority as well as opportunities to manage themselves according to objective conditions in them and in line with government policies regarding national education and decentralization. Winarno (2006: 2) suggests that to meet this need the Government feels the need to implement and develop a management model called School-Based Management.

\section{DISCUSSION}

Regional autonomy as a form of decentralization of government is essentially aimed at fulfilling the interests of the nation as a whole, namely efforts to get closer to the objectives of governance to realize the ideals of a better society, a more just and prosperous society. Law Number 23 the Year 2014 Article 1 (8) states that Decentralization is the surrender of Government Affairs by the Central Government to autonomous regions based on the Principle of Autonomy.

Decentralization is the transfer of authority of affairs which was originally the authority of the central government to the regional government to carry out these affairs. The authority to manage education has changed from a centralized system to a decentralized system. Decentralization of education means that there is a wider delegation of power and authority to the regions to make plans and make their own decisions in overcoming problems faced by education.

There are several things that must be fulfilled in the implementation of decentralization of education, namely: 1) the pattern and implementation of management must be democratic; 2) community empowerment must be the main goal; 3) community participation must be the main goal; 4) community participation not only in stakeholders, but must be an absolute part of the management system; 5) services must be faster, more efficient, more effective, exceeding centralized services for the benefit of students and the general public; and 6) the diversity of aspirations and values and local norms must be respected within the framework and for the strengthening of the national education system.

In line with the direction of the decentralization autonomy policy pursued by the government, the responsibil- ity of regional governments will be binding and increasingly broad, including in education management. Regional governments are expected to continuously improve their capabilities in various stages of education development since the stages of regional policy formulation, planning, implementation, monitoring or monitoring in each region are in line with the national education policy outlined by the government.

Even though the centralization of education, on the one hand, has a positive value, at least in this case the achievement of quality standards nationally, but on the other hand has no small impact. As a result of centralization, schools do not have the freedom to develop themselves, good schools will be hampered because they are forced to follow the rules of the central government, teachers become mere implementers of instructions, so they are not creative in accompanying students. In turn, schools will manipulate reports for the sake of good and for the sake of central demands that do not pay attention to local interests.

Thus, seeing the minus plus, however, the decentralization of education is a necessity, in addition to the demands of a number of prescribed laws and regulations demanding that they be implemented. Nevertheless, the implementation of decentralization of education should not be carried out through the mechanism of the surrender of bureaucratic power from the central government, because power has proven to fail in realizing quality education. Through a strategy of government decentralization in the field of education, the Ministry of Education and Culture is not only interested in developing districts/cities in managing education, but also has an interest in realizing education unit autonomy, namely autonomy at the school level.

To implement education decentralization nationally throughout the territory of Indonesia seems to experience various difficulties, due to a number of problems and obstacles that need to be overcome. Problems related to the substance of education management and legislation are as follows:

\subsection{Problems of Curriculum}

In the context of regional autonomy, the curriculum of an educational institution is not just a list of names of subjects demanded in a type and level of education. In a broader sense, the curriculum contains the conditions that have given birth to a specific lesson plan or program, also regarding the processes that occur within the institution (learning process), available facilities that support the occurrence of the process, and finally the product or outcome of the process.

The curriculum is all programs, facilities, and activities of an educational or training institution to realize the vision and mission of the institution. Therefore, the implementation of a curriculum to support the success of an educational institution must be supported by the following: 1) the availability of competent teaching staff (teachers); 2) availability of adequate and pleasant physical facilities or learning facilities; 3) the availability of assistive facilities for the teaching and learning process of supporting educa- 
tion staff, such as administrative staff, mentors, librarians, laboratory staff; 4) availability of adequate funds; 5) effective and efficient management; 6) maintaining a supportive culture such as religious, moral, national, and 7) visionary, transparent and accountable educational leadership.

\subsection{Problems of Human Resource}

Human resources are the most important pillar in implementing the decentralization of education. There are many concerns in the field of HR readiness, including not fulfilling employment opportunities with the ability of existing resources. However, the lack of professional human resources will hinder the implementation of the education system. The arrangement of human resources that is not in accordance with their educational background and expertise causes the implementation of unprofessional education. Many education personnel whose educational backgrounds are irrelevant are placed in the world of work they are engaged in.

\subsection{Problems with Education Funds, Facilities and}

\section{Infrastructure}

Law of the No. 20 of 2003 concerning the National Education System actually saved about the importance of the budget allocation of funds for financing and building this education. In article 49 paragraph (1) it is stated that education funds in addition to educator salaries and official education fees are allocated at least $20 \%$ of the State Budget (APBN) in the education sector and at least $20 \%$ of the Regional Budget (APBD).

Public funds that have been used to finance education have not been optimally allocated proportionally according to regional capacity. The absorption and centralized society have made the regions increasingly powerless to fund education. Educational facilities and infrastructure are very dependent on their views in the central government.

\subsection{Problems of Coaching and Coordination}

In the framework of implementing regional autonomy, the government is obliged to conduct maintenance so that problems that arise can be minimized. Even though decentralization is already in the regulations of the regional autonomy, but in the institutional and academic attitudes of the teachers, principals, and ranks of the education office as their superiors, it has not been synchronized. Local governments have not shown a clear appearance and way of working, and what they are doing is still using funds, not academic activities.

In practice, decentralization of education differs from decentralization in other areas of government, if decentralization in other areas of government is at the district/city level, then decentralization in the education sector does not stop at the district/city level but instead reaches educational institutions or schools spearhead of the implementation of education. In the practice of education decentralization that is what is called School-Based Management (Hasbullah, 2010: 12; Tanjung, 2019).
School-Based Management (SBM) Potentially offers community participation, equity, efficiency, and management that relies on the school level. School-Based Management (SBM) serves to ensure that the control of the central government is lower, but the increasing autonomy of schools to determine what needs to be taught and manage existing resources in schools to innovate and improvise.

The national education system is an integrated whole of all educational units and activities that are related to one another to try to achieve national goals. In this case, the national education system is a supra system, which is a large and complex system, which includes several parts which are also systems. The national education system aims to provide direction for all educational activities in existing educational units. The national education goals are the general objectives to be achieved by all educational units. Although each educational unit has its own goals, it is inseparable from the national education goals.

The government has established an autonomy policy for education, as referred to in Law No. 20 of 2003 concerning National Education System Article 53 concerning the Educational Legal Entity (BHP) that 1) Providers of funds/or formal education units established by the government or community in the form of educational legal entities. 2) Educational legal entities as referred to in paragraph (1) function to provide educational services to students. 3) The educational legal entity as referred to in paragraph (1) has a non-profit principle and can manage funds independently to advance the education unit. 4) provisions regarding educational legal entities are regulated by separate laws.

Based on the article above, the implementation of education is no longer the responsibility of the State but is left to the educational institution itself. Independence in the implementation of education is a condition to be achieved through the establishment of BHP, by implementing SBM in primary and secondary education, as well as autonomy in higher education. Only with independence, education can develop creativity, innovation, quality, flexibility, and mobility (Rivai and Murni, 2009: 35). This means that the government considers that so far the obstruction of the progress of Indonesian education has been partly due to centralized management so that the need for a decentralization policy of authority to advance Indonesia.

With the concepts of reform thinking, global culture, and regional autonomy, futures education must be developed more realistically in accordance with the guidance of the times (Chan and Sam, 2011: 196). Decentralization as an organizational concept implies delegation or delegation of power or authority from a leader or superior to a subordinate level in the organization. Decentralization is not intended to increase inequality between regions and centers or between regions in Indonesia, but to realize justice and prosperity by not ignoring diversity.

Satori (Engkoswara and Komariah, 2010: 292) argues that decentralization is the surrender of government affairs to the regions so that the authority and responsibility of the regions, including the determination of planning policies, 
the implementation would be related to the aspects of financing and officials. While decentralization of education is management system to realize educational development that emphasizes diversity.

The education system which has been managed in a bureaucratic and centralized climate is considered as one of the causes that have led to a deterioration in the quality and excellence of education. This is reasonable because the bureaucratic system always puts "power" as the most decisive factor in the decision-making process. Schools are shackled by the power of the bureaucracy starting from the power of the central level to the regions. Ironically, principals and teachers who are the ones who best understand the reality of education are in a controlled place. They should be the ones who play the most role as decision-makers in overcoming various daily problems that confront efforts to improve the quality of education, however, they are in a position of helplessness and pressure by various standards in the form of operational and technical guidelines that sometimes do not match the objective reality in each school .

The independence of each education unit has become a necessity and is one of the targets of the current education decentralization policy. Schools should be autonomous institutions by themselves, although the shift towards autonomous schools is a long way to go, requiring careful and in-depth study and planning. Through decentralization, education provides freedom, both to local governments and schools to make the best decisions about the implementation of education in the relevant region or school based on regional potential and school stakeholders. Decentralization of education in addition to being recognized as a political policy related to education is also a policy related to many things. The autonomy of the region, which is accompanied by decentralization of education or autonomy in the implementation of education, is expected to achieve the main objectives of the system restructuring program and education management.

The idea of School-Based Management needs to be well understood by all interested parties in the implementation of education, especially schools. Because the implementation of School-Based Management does not merely bring changes in the academic authority of the school and the management structure of the school. However, it also brings changes in the policy pattern and orientation of parents and community participation in school management.

Syamsuddin (Engkoswara and Komariah, 2010: 293) argues that school-based management is one alternative to school management within the framework of decentralization in the field of education that enables broad autonomy at the school level, high community participation so that schools are more flexible in managing resources and allocating them according to the priorities, needs, and local potential.

In implementing school-based management the role of school executives is prioritized. In connection with this problem, school-based management must be able to mobilize the resources of personnel, both internal and external schools, schools or other people related to schools to be able to play an active role in efforts to improve the quality of schools. In addition, management-based can carry out management functions in terms of organizing and utilizing resources in an effort to achieve school goals.

School-based management can be used by principals in an autonomous era of education in anticipating competency in HR development between regions and between schools. Schools have greater autonomy, community participation is enhanced through independent leadership of school principals with school committees exploring and utilizing resources that are in and within the school environment.

School-based management which is characterized by school autonomy and community involvement is the government's response to the symptoms that emerge in the community, aimed at improving education efficiency, quality, and equity. Increased efficiency, among others, is obtained through the flexibility to manage the resources of community participation and simplification of the bureaucracy. While improving quality can be obtained, among others, through parental participation in schools, flexibility in managing schools and classes, increasing the professionalism of teachers and principals, the enactment of incentive and disincentive systems. Increased equity, among others, is obtained through increasing community participation which allows the government to concentrate more on certain groups. This is possible because in some communities there is a high sense of ownership of the school.

According to Suparlan (2006:18) School-Based Management aims that schools that implement School-Based Management can provide better and more adequate education services for students. Schools become more qualified, the value of school exams or National exams become better, schools become a fun place to study, make schools where teachers have a career and devote themselves.

To achieve this goal the school needs to be given more authority in managing school resources. With School-Based Management, schools can plan school development, manage their own school resources, develop staff more optimally and engage the community more active in management.

School-based management gives great freedom and power to schools, accompanied by a set of responsibilities. With the existence of autonomy that gives responsibility for managing resources and developing SBM strategies in accordance with local conditions, schools can further improve the welfare of teachers so that they can be more concentrated in the task. Flexibility in managing resources in including the community to participate, encourages the professionalism of the principal, in his role as manager and school leader.

With the opportunity given to schools for developing curricula, teachers are encouraged to innovate, by experimenting with their school environment. As such, SBM encourages the professionalism of teachers and principals as 
educational leaders in schools. Through the preparation of elective curricula, school responsiveness towards local needs increases and guarantees educational services in accordance with the demands of students and the school community. Student achievement can be maximized through increasing parental participation, for example, parents can supervise directly the learning process of their children.

School-Based Management (SBM) emphasizes the maximum involvement of various parties, such as in private schools, thus ensuring broader participation of staff, parents, students and communities in the formulations of decisions about education. The opportunity to participate can increase their commitment to the school. Furthermore, these aspects will ultimately support effectiveness in achieving school goals. With community control and monitoring from the government, school management becomes more accountable, transparent, egalitarian and democratic, and removes the monopoly in the management of education. For this purpose, the readiness of managers is needed at various levels to carry out their roles according to their authority and responsibility.

School-Based-Management model in principle schools obtain delegation of authority that relies on schools and the community is included optimally, by itself will be far from the centralistic bureaucracy. Then make the school obtain a high obligation, authority, and responsibility in improving the school's performance for each interested party (Sagala, 2013: 158; Dariman, 2019; Ichsan, 2019).

According to Suparlan (2006: 18), in implementing School-Based Management, schools must pay attention to the 10 principles of School-Based Management, namely: openness, togetherness, sustainability, overall, accountability, democratic, independence, quality-oriented, minimum service achievement, and education for all.

Openness, meaning the school manager must be open to all acquisition and use of school resources to all parties with an interest in the school. Likewise, the activities carried out by the school are as open as the acquisition and use of funds. This means that anyone who wants to know what the school is doing must be allowed, and no one covered up the school. For example, the school attaches to the RAPBS and activity reports on the school bulletin board.

Togetherness, meaning that school management is done by involving the community. In this case, the community may be represented by the school committee providing inputs and also supervising the management of the school. Sustainability means that there is continuity in the management of the school. There is a connection between past policies and current policies. Everything does not start with zero. Comprehensive, meaning that school management must include all components that affect school success. Not as half-half, but looking at the interrelationships between managed components.

Accountability, meaning that the school manager must prepare responsibility for all actions and actions both when requested and not requested. At least every year there are reports on the implementation of activities that are the responsibility of the manager, willing to be examined, asked and provide an explanation of the subject matter that is his responsibility.

Democratic, meaning that every decision made is carried out on the basis of deliberation between the school and the community. Therefore meetings between schools and communities need to be held as often as possible in accordance with the urgency that arises. Independence, meaning that the school is able to stand alone and does not depend much on the help of others. In independence, schools have initiatives and innovations in order to achieve school goals.

Quality oriented, meaning that schools carry out their duties and functions not carelessly, but always strive for the best work results for stakeholders. In this case, the school always plans improvements in all fields from time to time. Achievement of minimum service standards, meaning that managers always strive so that minimum service standards can be met in full in a gradual and sustainable manner. Education for all, meaning the manager does not discriminate the opportunity to be served by the school. Because all children have the same right to education.

Ministry of National Education (2007: 13) establishes characteristics of school-based management consisting of (1) Granting broad autonomy to schools; (2) community and parent participation; (3) democratic and professional leadership; and (4) compact and transparent team-work. Explanations of the characteristics of school-based management are as follows:

Giving broad autonomy to schools. School-based management provides broad autonomy to schools, accompanied by a set of responsibilities for resource management and strategy development in accordance with local conditions, schools can further empower teacher education personnel to be more concentrated in their main task of teaching. Schools as educational institutions are given extensive authority and power to develop curriculum and learning programs in accordance with the conditions and needs of students and the demands of the community. To support the success of the program, schools have the power and authority to manage and utilize various resources available in the community and the surrounding environment. In addition, the school is also given the authority to explore and manage funding sources according to priority needs. Through extensive autonomy, schools can improve the performance of education personnel by offering their active participation in decision making and shared responsibility in implementing proportional and professional decisions taken.

Community participation and parents. In school-based management, the implementation of school programs is supported by community participation and high parents of students. Parents of students and communities not only support schools through financial assistance but through school committees and education councils formulate and develop programs that can improve school quality. Com- 
munities and parents collaborate to help schools as resource persons for various school activities to improve the quality of learning.

Democratic and professional leadership. In school-based management, the implementation of school programs is supported by the existence of democratic and professional school leadership. The principal and the teachers as the core implementing staff of the school program are people who have professional abilities and integrity. The principal is a professional education manager who is recruited by the school committee to manage all school activities based on the policy set. The teachers recruited by the school are professional educators in their respective fields, so they work based on patterns of convenience and support the learning success of students. In the decision-making process, the principal implements a democratic bottom-up process, so that all parties have responsibility for the decisions taken and their implementation.

Team-Work that is compact and transparent. In school-based management, the success of school programs is supported by the performance of a compact and transparent team-work from various parties involved in school education. In the education council and school committee, for example, the parties involved collaborate harmoniously according to their respective positions to create a school that can be proud of by all parties. They do not show each other the power or the most meritorious, but each contributes to efforts to improve the quality and performance of the school in a fixed manner. In the implementation of the program, for example, the relevant parties collaborate professionally to achieve the agreed-upon targets. Thus, the success of SBM is the result of a synergy and team collaboration that is compact and transparent.

School performance will be largely determined by the policies set by the school regarding curriculum development. However, in formulating school policies refers to central policies and takes into account the growing aspirations of local stakeholders through the school board. In maintaining school quality and performance with the principle of quality assurance and accountability the role of the center and school in monitoring evaluation is a system in an effort to improve quality. However, each has different authority, and responsibility.

\section{CONCLUSION}

Based on our review and results of study, there are two conclusion, that is:

1. Decentralization of education has encouraged the improvement of services in the field of education to the community, which leads to efforts to improve the quality of education management at the lowest level, namely schools through the implementation of School-Based Management (SBM).

2. Implementation of School-Based Management, in general, is to empower or empower schools through the granting of authority (autonomy) to schools, giving greater flexibility to schools to manage school resources, and encouraging the participation of school members and the community to improve education quality.

\section{REFERENCES}

Chan, Sam M. dan Tuti T. Sam. (2011). Analisis SWOT Kebijakan Pendidikan Era Otonomi Daerah. Jakarta: RajaGrafindo Persada.

Dariman, K. (2019). Students' Creative Thinking With 4'R Applications in Procedure Text Project Based Learning. International Journal for Educational and Vocational Studies, 1(1), 15-20.

Depdiknas. (2007). Manajemen Berbasis Sekolah. Jakarta: Direktorat Jenderal Manajemen Pendidikan Dasar dan Menengah.

Engkoswara dan Aan Komariah. (2010). Administrasi Pendidikan. Bandung: Alfabeta.

Fattah, Nanang. (2012). Analisis Kebijakan Pendidikan. Bandung: PT Remaja Rosdakarya.

Fattah, Nanang (2009). Landasan Manajemen Pendidikan. Bandung: Remaja Rosdakarya.

Hasbullah. (2010). Otonomi Pendidikan. Jakarta: Rajagrafindo Persada.

Ichsan, I. Z., Sigit, D. V., \& Miarsyah, M. (2019). Environmental Learning based on Higher Order Thinking Skills: A Needs Assessment. International Journal for Educational and Vocational Studies, 1(1), 21-24.

Kaufman R.A. (1973). Educational System Planning. New Jersey: Prentice Hall Inc.

Rivai, Veithzal dan Sylviana Murni. (2009). Education Management. Jakarta: RajaGrafindo Persada.

Sagala, Syaiful. (2013). Manajemen Strategik dalam Peningkatan Mutu Pendidikan. Bandung: Alfabeta.

Sa'ud, Udin Syaefudin dan Abin Syamsuddin Makmun. (2005). Perencanaan Pendidikan (Suatu Pendekatan Komprehensif). Bandung: Remaja Rosdakarya.

Suparlan et al. (2006). Pemberdayaan Komite Sekolah. Jakarta: Departemen Pendidikan Nasional.

Tanjung, R. F. (2019). Answering the Challenge of Industrial Revolution 4.0 Through Improved Skills Use of Technology College. International Journal for Educational and Vocational Studies, 1(1), 11-14.

Tilaar, H.A.R. (2009). Kekuasaan dan Pendidikan: Manajemen Pendidikan Nasional dalam Pusaran Kekuasaan. Jakarta: Rineka Cipta.

Tilaar, H.A.R. (2006). Standarisasi Pendidikan Nasional: Suatu Tinjauan Kritis. Jakarta: Rineka Cipta.

Tilaar, H.A.R. (2006). Manajemen Pendidikan Nasional (Kajian Pendidikan Masa Depan). Bandung: Remaja Rosdakarya.

Winarno. (2006). Tugas Pokok dan Fungsi Pengawas. Jakarta: Badan Diklat Depdagri dan Diklat Depdiknas.

Regulations references:

Undang-undang Dasar Negara Republik Indonesia Tahun 1945

Undang-undang Nomor 20 Tahun 2003 tentang Sistem Pendidikan Nasional.

Undang-undang Nomor 23 Tahun 2014 tentang Pemerintahan Daerah.

Peraturan Pemerintah Republik Indonesia Nomor 19 Tahun 2005 tentang Standar Nasional Pendidikan. 